\title{
Nitrogen isotopic composition of organic matter from a 168 year-old coral skeleton: Implications for coastal nutrient cycling in the Great Barrier Reef \\ Lagoon
}

Dirk V. Erler ${ }^{1}{ }^{*}$, Xingchen T. Wang ${ }^{2}$, Daniel M. Sigman ${ }^{2}$, Sander R. Scheffers ${ }^{1}$, Alfredo Martínez-García ${ }^{3}$, Gerald H. Haug ${ }^{3}$

${ }^{1}$ School of Environment Science and Engineering, Southern Cross University, Lismore, NSW 2480, Australia

${ }^{2}$ Department of Geosciences, Guyot Hall, Princeton University, Princeton, NJ 08540, USA

${ }^{3}$ Geological Institute, ETH Zürich, 8092 Zürich, Switzerland

*Corresponding author. Tel.: +61 26620 3256, Email: dirk.erler@scu.edu.au 
Keywords: stable isotope analysis, nitrogen cycle, coral skeleton, Great Barrier Reef 


\section{Abstract}

Ongoing human activities are known to affect nitrogen cycling on coral reefs, but the full history of anthropogenic impact is unclear due to a lack of continuous records. We have used the nitrogen isotopic composition of skeleton-bound organic matter $\left(\mathrm{CS}-\delta^{15} \mathrm{~N}\right)$ in a coastal Porites coral from Magnetic Island in the Great Barrier Reef as a proxy for $\mathrm{N}$ cycle changes over a 168 year period (1820 - 1987 AD). The Magnetic Island inshore reef environment is considered to be relatively degraded by terrestrial runoff; given prior $C S-\delta^{15} \mathrm{~N}$ studies from other regions, there was an expectation of both secular change and oscillations in CS- $\delta^{15} \mathrm{~N}$ since European settlement of the mainland in the mid 1800's. Surprisingly, CS$\delta^{15} \mathrm{~N}$ varied by less than $1.5 \%$ despite significant land use change on the adjacent mainland over the 168-year measurement period. After $1930, \mathrm{CS}-\delta^{15} \mathrm{~N}$ may have responded to changes in local river runoff, but the effect was weak. We propose that natural buffering against riverine nitrogen load in this region between 1820 and 1987 is responsible for the observed stability in $\mathrm{CS}-\delta^{15} \mathrm{~N}$. In addition to coral derived skeletal $\delta^{15} \mathrm{~N}$, we also report, for the first time, $\delta^{15} \mathrm{~N}$ measurements of non-coral derived organic $\mathrm{N}$ occluded within the coral skeleton, which appear to record significant changes in the nature of terrestrial $\mathrm{N}$ inputs. In the context of previous $\mathrm{CS}-\delta^{15} \mathrm{~N}$ records, most of which yield $\mathrm{CS}-\delta^{15} \mathrm{~N}$ changes of at least $5 \%$, the Magnetic Island coral suggests that the inherent down-core variability of the $C S-\delta \delta^{15} \mathrm{~N}$ proxy is less than $2 \%$ for Porites. 


\subsection{Introduction}

Every year, 70-100 $\mathrm{Tg}$ of anthropogenic fixed $\mathrm{N}$ is transported into the coastal ocean through either riverine transport or atmospheric deposition (Fowler et al., 2013). The release of inorganic reactive $\mathrm{N}$ is thought to be a major driver of coastal ecosystem decline worldwide (Elser et al., 2007), and coral reefs of naturally oligotrophic tropical waters would seem particularly vulnerable (Carpenter et al., 1998).

It is generally accepted that coastal reef systems, including those of the Great Barrier Reef (GBR), are highly susceptible to eutrophication associated with terrestrial runoff (Brodie et al., 2011). Evidence to date suggests that agricultural activity since European settlement in the mid 1800's has increased the flux of sediments and nutrients to the nearshore GBR (Furnas, 2003; Kroon et al., 2012; McCulloch et al., 2003). Furthermore, spatial changes in coral reef composition have been associated with declining water quality gradients (Fabricius et al., 2005), with many inshore reef systems already considered eutrophic (Bell, 1992; Bell and Elmetri, 1995; Brodie et al., 2011). However, in the GBR, there is still no clarity as to the historical changes that have occurred as a result of anthropogenic nutrient inputs, mostly due to a lack of long term records of coastal water quality (Fabricius et al., 2005; Koop et al., 2001; Wooldridge et al., 2006).

Changes in $\mathrm{N}$ availability are typically accompanied by shifts in the isotopic composition of the $\mathrm{N}\left(\delta^{15} \mathrm{~N}\right.$ (in permil, \%o $)=1000 *\left(\left({ }^{15} \mathrm{~N} /{ }^{14} \mathrm{~N}\right)\right.$ sample $\left./\left({ }^{15} \mathrm{~N} /{ }^{14} \mathrm{~N}\right)_{\text {reference }}-1\right)$, where the ${ }^{15} \mathrm{~N} /{ }^{14} \mathrm{~N}$ reference is $\mathrm{N}_{2}$ in air). This is particularly true if the isotope signature of the $\mathrm{N}$ source changes; for example, an increase in fertiliser runoff is often associated with a drop in the $\delta^{15} \mathrm{~N}$ of fixed $\mathrm{N}$ dissolved in the coastal water column and particulate $\mathrm{N}$ suspended in it (Kendall et al., 2007). Numerous studies have suggested that these anthropogenically induced shifts in $\delta^{15} \mathrm{~N}$ are recorded by benthic marine organisms such as corals (Baker et al., 2010b; Hoegh-Guldberg et al., 2004; Sammarco et al., 1999; Sherwood et al., 2010), and macroalgae 
(Costanzo et al., 2001). The $\delta^{15} \mathrm{~N}$ signal of boulder forming hard coral tissue is well preserved within the skeleton (Muscatine et al., 2005; Yamazaki et al., 2013), and several studies have now used the $\delta^{15} \mathrm{~N}$ of hard coral skeleton-bound organic $\mathrm{N}\left(\mathrm{CS}-\delta^{15} \mathrm{~N}\right)$ to try and detect temporal and spatial changes in the $\delta^{15} \mathrm{~N}$ anthropogenic $\mathrm{N}$ discharges (Jupiter et al., 2008; Lewis et al., 2012; Marion et al., 2005; Yamazaki et al., 2011).

However the $\mathrm{CS}-\delta^{15} \mathrm{~N}$ of hard corals will also respond to ecosystem shifts driven by changes in $\mathrm{N}$ availability. For instance, increased $\mathrm{N}$ loads to coral reefs lead to changes in microbial community structure (Furnas et al., 2005) and prey availability for higher trophic levels, which can cause changes to the $\delta^{15} \mathrm{~N}$ of zooplankton (McClelland and Montoya, 2002). Food-web structure in a marine ecosystem therefore affects the $\delta^{15} \mathrm{~N}$ of the different components of that ecosystem (Michener and Kaufman, 2007), some of which are accessed during feeding by corals. Moreover, and separate from any $\delta^{15} \mathrm{~N}$ change in a given prey item, both physiological and trophic changes in zooxanthellate corals can alter their tissue $\delta^{15} \mathrm{~N}$ (Erler et al., 2015; Reynaud et al., 2009; Wang et al., 2015). Anthropogenic N enrichment therefore works to alter CS- $\delta^{15} \mathrm{~N}$ in multiple ways, including: (1) changes in the $\delta^{15} \mathrm{~N}$ of the source of inorganic and particulate $\mathrm{N}$ to a system; (2) changes in the $\delta^{15} \mathrm{~N}$ of $\mathrm{N}$ available to the coral through shifting food-web structure; and (3) changes in the internal cycling of $\mathrm{N}$ between coral and symbiont as a result of coral feeding rate and/or zooxanthellae growth rate (Table 1). Given all of these factors, barring a remarkable coincidence of offsetting effects, an ecologically consequential anthropogenic nutrient enrichment on a coral reef will cause a measurable change in the $\mathrm{CS}-\delta^{15} \mathrm{~N}$ of resident corals.

Most of the previous tropical hard coral $\mathrm{CS}-\delta^{15} \mathrm{~N}$ records appear to support the view that anthropogenic activity has significantly altered coastal ocean N cycling (Jupiter et al., 2008; Marion et al., 2005; Yamazaki et al., 2011; Yamazaki et al., 2015). However, many of the analytical protocols previously used did not sufficiently clean the coral skeletal samples 
to remove potential contaminants from non-coral derived organic $\mathrm{N}$, or foreign organic $\mathrm{N}$ (FON), that become occluded within the coral skeleton during calcification. Furthermore many of the previous studies isolated only the acid insoluble organic fraction of the skeletal organic material, causing potential bias in their $\mathrm{CS}-\delta^{15} \mathrm{~N}$ records. Both these factors could have limited their capacity to support detailed historical studies of coral skeletal $\delta^{15} \mathrm{~N}$ as a proxy of environmental change.

Recently a new method was developed in which the organic $\mathrm{N}$ from small quantities (e.g. $5 \mathrm{mg}$ ) of aggressively cleaned coral powders is oxidised and bacterially converted to $\mathrm{N}_{2} \mathrm{O}$ for analysis of $\delta^{15} \mathrm{~N}$ via isotope ratio mass spectrometry (Wang et al., 2015). The new method for CS- $\delta^{15} \mathrm{~N}$ analysis is adequately precise $(1 \sigma=0.2 \%$ ) to capture even modest changes in CS- $\delta^{15} \mathrm{~N}\left(\right.$ Wang et al., 2015). Further, it has already been shown that $C S-\delta^{15} \mathrm{~N}$ measured in this way can be used to trace small $(\sim 1 \%)$ spatial fluctuations in external water column $\delta^{15} \mathrm{~N}$ (Erler et al., 2015). The natural progression in the development of this new proxy is the reconstruction of long-term (> $100 \mathrm{yr}$ ) temporal $\mathrm{CS}-\delta^{15} \mathrm{~N}$ records at semiannual/annual resolution.

In this study we have applied the new $\mathrm{CS}-\delta^{15} \mathrm{~N}$ technique to try and detect changes in the $\mathrm{N}$ cycling dynamics of a coastal reef in the GBR (Fig. 1) from 1820 to 1987 AD, testing the hypothesis that $\mathrm{CS}-\delta^{15} \mathrm{~N}$ from a coastal GBR coral has been altered substantially by the previously reported increases in the input of anthropogenic fixed $\mathrm{N}$ over that period.

\subsection{Methods}

\subsection{Coral cores}

This work is based on the analysis of coral skeleton organic material from four coral colonies. The main coral core used in this study was drilled from a large Porites colony 
situated in Geoffrey Bay, Magnetic Island (19.15 S, $\left.146.87^{\circ} \mathrm{E}\right)$ (Fig. 1) in 1987. Magnetic Island is a $52 \mathrm{~km}^{2}$ inshore continental island within the central portion of the GBR lagoon. The island lies roughly $8 \mathrm{~km}$ offshore from the city of Townsville, and in the path of flood plumes debouched from the Burdekin River, the largest source of freshwater to the GBR lagoon. The water quality of the Magnetic Island reef system is considered to be relatively degraded and this has been attributed to anthropogenic activity on the adjacent mainland, and in particular to nutrient and sediment discharge from the Burdekin River (Brodie et al., 2011; Devlin and Brodie, 2005; Furnas, 2003; Lewis et al., 2007; Wooldridge et al., 2006). While particulate $\mathrm{N}$ released from the Burdekin River is known to be removed within $10 \mathrm{~km}$ of the river mouth, dissolved inorganic from terrestrial runoff and sediment mineralisation is transported as far as Magnetic Island during heavy rainfall events (Bainbridge et al., 2012).

Additional Porites cores were collected from three reefs in the northern section of the GBR (Fig. 1, top inset), a region still considered to be in pristine condition (De'ath et al., 2012). The three northern GBR cores (NR1, 2 and 3) were collected in 1990 from reefs situated 14,43 and $40 \mathrm{~km}$ from the mainland respectively $\left(12.51^{\circ} \mathrm{S} 143.52^{\circ} \mathrm{E}, 12.38^{\circ} \mathrm{S}\right.$ $\left.143.74^{\circ} \mathrm{E}, 13.3^{\circ} 3 \mathrm{~S} 143.96^{\circ} \mathrm{E}\right)$. All cores were collected by the Australian Institute of Marine Science (AIMS). Collected cores were sectioned into $7 \mathrm{~mm}$ slabs at AIMS.

\subsection{CS- $\delta^{15} \mathrm{~N}$ measurement}

Coral slabs were x-rayed to identify annual growth bands, sonicated to remove surface contamination, and then dried. Between 5-10 mg of skeletal material was drilled from each annual high and low density band with a hand held drill after the surface aragonite (about $1 \mathrm{~mm}$ ) was ground away to reveal clean skeletal material beneath . For the Magnetic Island core, an additional high and low density band was sampled from every fifth year of skeletal growth to determine the precision of the analytical method. The age model was determined by counting the growth bands. The age of the Magnetic Island core was 
calculated to be 168 years old (1820 to 1987) while the three northern GBR cores were 17 (1974 - 1990), 18 (1973 - 1990) and 16 (1975 - 1990) years old (NR1, NR2 and NR3 respectively).

The detailed protocol and method validation for the extraction and analysis of CS$\delta^{15} \mathrm{~N}$ is described by Wang et al. (2015). Briefly, coral powders were cleaned with sodium hypochlorite to remove any contamination, washed, dried and dissolved by reaction with $\mathrm{HCl}$. Samples were oxidised with persulphate to yield $\mathrm{NO}_{3}{ }^{-}$, the $\delta^{15} \mathrm{~N}$ of which was measured following conversion to $\mathrm{N}_{2} \mathrm{O}$ via the denitrifier method (Sigman et al., 2001). Results from the high- and low-density bands from each year were averaged to give annual data points. The precision of the method, calculated from the replicate measurements $(n=4)$ made every fifth year of growth, was $0.2 \%$ ( $(1 \sigma)$.

\subsection{Foreign organic nitrogen in the coral skeleton}

In this study we measure the $\mathrm{N}$ content and $\delta^{15} \mathrm{~N}$ of FON in a coral skeleton by comparing cleaned and uncleaned coral powders from the Magnetic Island core. The distinctive luminescent banding observed within coral skeletons has been linked to the discharge of terrestrially derived humic acids (Grove et al., 2010; Isdale, 1984; Lough, 2011) and we chose these most intense luminescent intervals to perform the comparison.

Using a UV light, the 40 most intense luminescent lines were selected in the Magnetic Island core. About $20 \mathrm{mg}$ of coral powder was drilled from these growth bands. Half the powder from each of the selected luminescent lines was bleach cleaned to remove entrapped non-coral-native organic N (Ramos-Silva et al., 2013), and the other half remained unbleached. Both samples were then analysed as above for $\delta^{15} \mathrm{~N}$. A replicate set of powders was collected and analysed from every $4^{\text {th }}$ luminescent line. A simple mixing calculation, equation (1), was used to determine the $\delta^{15} \mathrm{~N}$ content of the FON $\left(\mathrm{FON}-\delta^{15} \mathrm{~N}\right)$. 
FON $-\delta{ }^{15} \mathrm{~N}=\frac{\left(\mathrm{UC}-\delta^{15} \mathrm{~N}\right) \times(\mathrm{UC}-\mathrm{N})-\left(\mathrm{CL}-\delta^{15} \mathrm{~N}\right) \times(\mathrm{CL}-\mathrm{N})}{(\mathrm{UC}-\mathrm{N})-(\mathrm{CL}-\mathrm{N})}$

Equation (1)

Where $\mathrm{UC}-\delta^{15} \mathrm{~N}$ is the $\delta^{15} \mathrm{~N}$ of the uncleaned skeletal organic material; UC-N is the total $\mathrm{N}$ content of the uncleaned sample ( $\mu \mathrm{mol} \mathrm{N} \mathrm{g}{ }^{-1}$ ); and CL-N is the $\mathrm{N}$ content of the cleaned sample. Error propagation during the calculation of $\mathrm{FON}-\delta^{15} \mathrm{~N}$ was determined using the results from the replicate analysis and the equations of Hayes (Hayes, 1983).

\section{$2.4 \delta^{18} \mathrm{O}$ and linear extension rates}

For the analysis of the $\delta^{18} \mathrm{O}$ signature of the carbonate material from the Magnetic Island coral, 100 to $150 \mu \mathrm{g}$ of milled powders were analysed with a Thermo GasBench II coupled to a Thermo Delta V plus mass spectrometer using published protocols (Breitenbach and Bernasconi, 2011). External reproducibility $(1 \sigma)$ of carbonate standards was better than $\pm 0.06 \%$ during the analysis. Isotope values were calibrated to the Vienna Peedee Belemnite scale (VPDB) with the NBS-19 carbonate standard.

Linear extension rates were determined after analysis of density banding in coral core X-rays. Analysis was performed with Coral-XDS ${ }^{\odot}(\mathrm{V} 3.0)$ software. Extension rates were calculated from measured distances between adjacent high density growth bands. Burdekin River discharge data for the period 1820 to 1987 were based on previous reconstructions (Lough, 2007), and for the period 1920 to 1987 from instrumental records in the Queensland government archives (www.dnrm.qld.gov.au/water).

\subsection{Statistical Analysis}

Comparison of the variances in $\mathrm{CS}-\delta^{15} \mathrm{~N}$ between the four coral cores was performed with Levine's test for homogeneity of variances in SPSS. Comparisons were made between data from the three northern GBR cores (1974 - 1990, 1973 - 1990 and 1975 - 1990 for 
NR1, NR2 and NR3 respectively) and the Magnetic Island core data for the period 1820 1987.

The strength of correlations between $\mathrm{CS}-\delta^{15} \mathrm{~N}$ and the other parameters $\left(\delta^{18} \mathrm{O}\right.$, LER, and Burdekin River discharge) were determined using the Spearman's rank-order correlation test on normalised data. For the correlation analysis, data were normalised to the average value between 1820 and 1840 and, in the case of the instrumental Burdekin River discharge data, to the average value between 1820 and 1830 .

\subsection{Results}

\subsection{Coral skeletal $\delta^{15} \mathrm{~N}$}

The yearly and Gaussian filtered (5 year) $\mathrm{CS}-\delta^{15} \mathrm{~N}$ data from the Magnetic Island core are shown in Fig. 2a. The range in the Magnetic Island CS- $\delta^{15} \mathrm{~N}$ record was less than $1.5 \%$ over the 168 year measurement period. In the first 40 years of the record $(1820-1860)$, the $\mathrm{CS}-\delta^{15} \mathrm{~N}$ remained within a $\sim 0.6 \%$ range, with an average value of $6.65 \pm 0.15 \%$ o $(1 \sigma)$. After 1860, the variation in $\mathrm{CS}-\delta^{15} \mathrm{~N}$ became more pronounced, but $\mathrm{CS}-\delta^{15} \mathrm{~N}$ still remained within the $1.5 \%$ range, averaging $6.80 \pm 0.30 \%$ ( $1 \sigma)$ for 1860 to 1987 . Below, we describe the results of the correlation analysis between $\mathrm{CS}-\delta^{15} \mathrm{~N}$ and other properties over the record, but we emphasize here that our measured $\mathrm{CS}-\delta^{15} \mathrm{~N}$ variation is minor in comparison to modern spatial $\delta^{15} \mathrm{~N}$ variation in corals and other reef $\mathrm{N}$ pools (Marion et al., 2005; Risk et al., 2009a; Risk et al., 2009b; Yamazaki et al., 2011).

There is no significant correlation between Burdekin River discharge (Fig. 2b, from the data of Lough (2007)) and CS- $\delta^{15} \mathrm{~N}$ between 1820 and 1987. However, for the period 1930 to 1987, the correlation between instrumental Burdekin River discharge (Fig. 2b) and CS- $\delta^{15} \mathrm{~N}$ is significant and negative $\left(\mathrm{r}_{\mathrm{s}}=-0.33, \mathrm{p}<0.05\right)$. The carbonate $\delta^{18} \mathrm{O}$ and the measured linear extension rate (LER) for the Magnetic island core are plotted in Fig. 2c and 
$2 \mathrm{~d}$ respectively. Warm wet periods, reflected by lower $\delta^{18} \mathrm{O}$, appear to coincide with high Burdekin River discharge and lower $\mathrm{CS}-\delta^{15} \mathrm{~N}$ from 1936 onwards, but these correlations are not significant. Similarly there is no correlation between LER and Burdekin River discharge or $\mathrm{CS}-\delta^{15} \mathrm{~N}$ over the measurement periods 1820 to 1987 or 1930 to 1987.

The CS- $\delta{ }^{15} \mathrm{~N}$ for the Magnetic Island core was compared with CS- $\delta{ }^{15} \mathrm{~N}$ from three cores collected in the pristine far-northern section of the GBR (Fig. 1). The mean CS- $\delta^{15} \mathrm{~N}$ values from the four cores were all statistically different $(\mathrm{p}<0.05)$ from each other $($ Fig. 3$)$. The mean CS- $\delta{ }^{15} \mathrm{~N}$ between 1980 and 1987 from the Magnetic Island core was statistically higher than prior to 1980 (Fig. 3). Spatial differences in $\mathrm{CS}-\delta^{15} \mathrm{~N}$ may be indicative of reefspecific $\mathrm{N}$ cycling, however, of greater relevance here is a comparison of the variance in CS$\delta{ }^{15} \mathrm{~N}$ over time between the far-northern corals and the Magnetic Island coral, which offers an additional indication of whether the latter has experienced significant anthropogenic disturbance. The variance in CS- $\delta^{15} \mathrm{~N}$ for the Magnetic Island core and from two of the northern reefs (NR1 and NR2) were not statistically different $(\mathrm{p}>0.05)$ (Fig. 3), implying that the level of disturbance in $\mathrm{CS}-\delta^{15} \mathrm{~N}$ from the Magnetic Island coral was similar to that in two of the three corals collected from the pristine northern section of the GBR. Only comparison with NR3 suggested a greater variance in the Magnetic Island core.

\subsection{Potential contamination with non-coral derived $\mathbf{N}$}

Of earlier studies that report temporal records of $\mathrm{CS}-\delta^{15} \mathrm{~N}$ in tropical hard corals, many did not clean the coral powders with an oxidising agent, such that non-coral derived organic material, which we call foreign organic $\mathrm{N}(\mathrm{FON})$, may also have been included in the analysis of CS- $\delta^{15}$ N. Ramos-Silva et al. (2013) highlight the potential contamination of the coral-native organic $\mathrm{N}$ occluded within the precipitated mineral phase with foreign organic compounds entrapped in skeletal cavities. This FON can include endolithic algal remnants and humic acids (Boto and Isdale, 1985; Titlyanov et al., 2008). 
The work of Wang et al. (2015) shows that uncleaned coral powders contain more N, and can have different $\mathrm{CS}-\delta^{15} \mathrm{~N}$, than cleaned powders. In the present study, we sought to ensure that the sodium hypochlorite cleaning protocol was effective at removing FON from the coral skeleton. Hence we ran a number of duplicate samples in which the powders were not hypochlorite-cleaned. Powders from intense luminescent lines were chosen for the comparison because luminescent lines are thought to be associated with the inclusion of humic acid FON (Boto and Isdale, 1985; Susic et al., 1991), arguably increasing the potential for observing a difference between cleaned and uncleaned samples. We measured the $\mathrm{N}$ content and $\delta^{15} \mathrm{~N}$ of the uncleaned powders (Fig. 4a, blue symbols; $\mathrm{N}$ content not shown). From these data and the data on $\mathrm{CS}-\delta^{15} \mathrm{~N}$ and $\mathrm{N}$ content, the $\delta^{15} \mathrm{~N}$ of FON $\left(\mathrm{FON}-\delta^{15} \mathrm{~N}\right)$ was calculated (Fig. 4, red symbols; see section 2.3).

The $\delta^{15} \mathrm{~N}$ of the uncleaned powders and thus the $\mathrm{FON}-\delta^{15} \mathrm{~N}$ had a long term trend, with a FON- $\delta^{15} \mathrm{~N}$ difference of $9.7 \%$ between the lowest (1847) and highest (1961) values (Fig. 4a, blue symbols), far in excess of the variability observed in $\mathrm{CS}-\delta^{15} \mathrm{~N}$. Without the removal of the FON from the coral powders, we could have erroneously concluded that $\delta^{15} \mathrm{~N}$ in the coastal waters surrounding Magnetic Island has increased over the 170 year measurement period (Fig. 4a). The amount of $\mathrm{N}$ associated with FON is consistently less than the amount of $\mathrm{N}$ associated with the $\mathrm{CS}-\delta^{15} \mathrm{~N}$, i.e. $\mathrm{N}$ extracted from cleaned coral skeleton (Fig. 4b). While the concentration of FON shows no trend over the coral record (Fig. 4b), the FON $-\delta^{15} \mathrm{~N}$ increases with time $\left(\mathrm{R}^{2}=0.58, \mathrm{P}<0.001\right)($ Fig. $4 \mathrm{a})$.

\subsection{Discussion}

\subsection{Comparison with other coral records of $\delta^{15} \mathrm{~N}$}

In this study we have used a newly developed isotopic technique to measure the CS$\delta^{15} \mathrm{~N}$ in a 168 year old coastal Porites coral from the inshore GBR. The proxy has been 
applied to detect small (<3\%) spatial changes in CS- $\delta^{15} \mathrm{~N}$ (Erler et al., 2015; Wang et al., 2015) but this is its first application to a long lived coral skeleton. Given 1) the spatial sensitivity of the new $\mathrm{CS}-\delta^{15} \mathrm{~N}$ proxy, 2) that the inshore GBR is considered to be relatively degraded by increases in terrestrial nutrient runoff since the mid-1850's, and 3) that perturbations to $\mathrm{N}$ cycling affect the $\delta^{15} \mathrm{~N}$ of resident organisms, we expected to observe significant shifts in $\mathrm{CS}-\delta^{15} \mathrm{~N}$ over the 168 year measurement period. However, surprisingly, the $\mathrm{CS}-\delta^{15} \mathrm{~N}$ record from the Magnetic Island coral was largely stable over the 168 year measurement period.

The stability of the Magnetic Island CS- $\delta^{15} \mathrm{~N}$ record is in stark contrast to all previous temporal CS- $\delta^{15} \mathrm{~N}$ records derived from boulder forming hard corals (Fig. 5a) which can show changes of $\sim 10 \%$ within a single colony (Jupiter et al., 2008; Marion et al., 2005; Yamazaki et al., 2015). Jupiter et al. (2008) found that the $\mathrm{CS}-\delta^{15} \mathrm{~N}$ (of the acid insoluble fraction of coral skeletal organic N) was abruptly elevated during two major flood events in the Southern GBR. Based on our analyses, which yielded values up to $10 \%$ in $\mathrm{FON}-\delta^{15} \mathrm{~N}$, we raise the possibility that the flood induced elevation of the insoluble CS- $\delta^{15} \mathrm{~N}$ reported by Jupiter et al. (2008) is caused by the presence of FON trapped in the skeleton and not a direct result of changes to the coral-native $\mathrm{N}$. This may also account for some of the large variations in $\delta^{15} \mathrm{~N}$ observed in other past studies based on the measurement of insoluble organic matter from uncleaned or weakly cleaned skeletal material (Lewis et al., 2012; Marion et al., 2005) (Fig. 5a). To be clear, we have no direct evidence that such effects have been important in any prior study. However, our data show clearly that the presence of FON can be a significant driver of noise and possibly of secular trends in a $\mathrm{CS}-\delta^{15} \mathrm{~N}$ record.

With regard to our own data, the lack of correlation between $\mathrm{FON}-\delta^{15} \mathrm{~N}$ and $\mathrm{CS}-\delta^{15} \mathrm{~N}$ argues that $\mathrm{CS}-\delta^{15} \mathrm{~N}$ is not affected or contaminated by environmentally derived organic matter associated with the coral skeleton. More generally, the reported $\mathrm{CS}-\delta^{15} \mathrm{~N}$ record 
indicates that the inherent variability of the CS- $\delta^{15} \mathrm{~N}$ proxy is low, $<2 \%$ and probably $<1 \%$, suggesting that relatively subtle isotopic signals should be recoverable using this developing technique. Because of the large $\delta^{15} \mathrm{~N}$ changes observed in previous studies, up to this time, the inherent stability of $\mathrm{CS}-\delta^{15} \mathrm{~N}$ in the context of a down-core record has not been clear. At the very least, this study has successfully demonstrated that the new technique is applicable to long lived coral cores, and is immune to the very large swings in CS- $\delta^{15} \mathrm{~N}$ observed in previous studies. We are confident that moving forward the described $\mathrm{CS}-\delta^{15} \mathrm{~N}$ proxy will be an important tool in the study of $\mathrm{N}$ cycling on coral reefs.

\subsection{Foreign organic $N$}

As well as CS- $\delta^{15} \mathrm{~N}$, we also measured the $\delta^{15} \mathrm{~N}$ of foreign organic $\mathrm{N}\left(\mathrm{FON}-\delta^{15} \mathrm{~N}\right)$ within the Magnetic Island coral core. Initially our intention was to demonstrate the utility of sodium hypochlorite cleaning on $\mathrm{CS}-\delta^{15} \mathrm{~N}$, however the pattern observed in the $\mathrm{FON}-\delta^{15} \mathrm{~N}$ record illustrates that in itself it may be an important new proxy record of anthropogenic change in coral reef environments.

We found that the FON- $\delta^{15} \mathrm{~N}$ increases dramatically over the time period covered by the coral core. Beyond its methodological implications, this increase may have an important environmental cause. Providing an explanation for the increase in $\mathrm{FON}-\delta^{15} \mathrm{~N}$ relies on understanding the source of the FON, and this is not clearly constrained by our data set. However, given that we chose the most intense luminescent lines in the coral skeleton, we propose that humic acids provided the bulk of the FON, and that changes in the $\delta^{15} \mathrm{~N}$ of humic acids are responsible for the observed change in $\mathrm{FON}-\delta^{15} \mathrm{~N}$.

Early studies (Boto and Isdale, 1985; Susic et al., 1991) found strong correlations between river run-off and luminescent bands. This included the observation that elevated concentrations of humic acids were associated with coral skeleton luminescent lines and that 
the humic acids were similar to those derived from soil (Susic et al., 1991). However, others have argued that the luminescent lines in offshore corals, mostly removed from terrestrial sediment input, point to salinity induced changes in skeletal density as the cause of luminescence (Barnes and Taylor, 2001). Based on the evidence to date, it appears that the brighter more distinct lines present in coastal corals are caused by changes in skeletal chemistry, including the incorporation of humic acids during high runoff events (Barnes and Taylor, 2005; Grove et al., 2010; Lough, 2011). Llewellyn et al. (2012) present a model in which humic acids diffuse through the coral tissue layer into the calicoblastic fluid, where they then become incorporated into the skeleton. If so, humic acids contribute to the pool of contaminants that are trapped in the skeletal voids during calcification. Such material would be removed via the sodium hypochlorite treatment (Ramos-Silva et al., 2013), fitting our observations.

If the FON measured in this study is largely composed of humic acids, then a potential explanation arises for the increase in $\mathrm{FON}-\delta^{15} \mathrm{~N}$ since the early 1800 's. Humic acids in coral skeletons are regarded as a proxy for humic acid runoff and related changes in catchment precipitation and soil erosion (Grove et al., 2010). The $\delta^{15} \mathrm{~N}$ of humic acids is known to increase with age (Kerley and Jarvis, 1997); this has been related to the finding that in soil profiles, the deeper more refractory humic material is higher in $\delta^{15} \mathrm{~N}$ than leaf litter in a given terrestrial environment (Hobbie and Ouimette, 2009; Huygens et al., 2008). This raises the possibility that the rise in $\mathrm{FON}-\delta^{15} \mathrm{~N}$ signals an increase in the age of humic material delivered to the Magnetic Island reef due to the erosion of deeper soil layers exacerbated by agriculture. This would be consistent with the expectation that the topsoil in the Burdekin catchment is not being replenished at a rate equivalent to that of soil loss.

Potential explanations for the $\mathrm{FON}-\delta^{15} \mathrm{~N}$ rise aside, the rise itself has implications for coral $\mathrm{N}$ biogeochemistry. Specifically, the $\mathrm{CS}-\delta^{15} \mathrm{~N}$ shows no indication of paralleling the rise 
in humic acid $\delta^{15} \mathrm{~N}$. This is consistent with the view that these humic inputs are not an important $\mathrm{N}$ source to this Magnetic Island coral or its ecosystem. The increase in $\mathrm{FON}-\delta^{15} \mathrm{~N}$ also stands to highlight the stability in the CS- $\delta^{15} \mathrm{~N}$ from the Magnetic Island core against a reported backdrop of increased terrestrial nutrient discharge in the region.

\subsection{The Magnetic Island CS- $\delta^{15} \mathrm{~N}$ record in the context of coastal changes since 1820}

Numerous studies of proteinaceous corals and organic-rich components of other organisms from coastal regions typically show significant $\delta^{15} \mathrm{~N}$ shifts as a result of anthropogenic activity (e.g., due to sewage discharge or fertiliser runoff) (Fig 5b) (Baker et al., 2010a; Baker et al., 2010b; Dailer et al., 2010; Heikoop et al., 2000; Lapointe et al., 2010; Risk et al., 2009b; Sherwood et al., 2010; Ward-Paige et al., 2005). Corals are sensitive 'bioindicators" because they record $\delta^{15} \mathrm{~N}$ changes in both the inorganic and organic $\mathrm{N}$ fractions (Hoegh-Guldberg et al., 2004), and many studies have capitalised on this to demonstrate the spatial and temporal extent of anthropogenic $\mathrm{N}$ enrichment (Fig. 5).

In relation to boulder forming hard corals, changes in $\mathrm{N}$ cycling such as shifts in plankton abundance can also be registered in $\mathrm{CS}-\delta^{15} \mathrm{~N}$. For example, using the same methods as employed here, a $3 \%$ increase was observed in the CS- $\delta^{15} \mathrm{~N}$ of Diploria labyrinthiformis from the rim reef of the Bermuda pedestal to the inner lagoon (Wang et al., 2015), a gradient mostly explained as the result of productivity-driven differences in the coral host/symbiont $\mathrm{N}$ cycle. In Porites lutea and Favia stelligera, Erler et al. (2015) observed a 1\%o change in CS- $\delta^{15} \mathrm{~N}$ across a $250 \mathrm{~m}$ reef flat transect, in this case resulting from a water column gradient in dissolved and particulate $\delta^{15} \mathrm{~N}$. Using similar methods but with a sodium hydroxide (not specifically oxidative) cleaning, Yamazaki et al. (2011) connected a 5.6\%o cross-reef gradient in CS- $\delta^{15} \mathrm{~N}$ to the $\delta^{15} \mathrm{~N}$ of nitrate originating from a river mouth, and variations in $\mathrm{CS}-\delta^{15} \mathrm{~N}$ of up to $14 \%$ from a 52 year old Porites coral off the Ryukyu Islands in Japan (Yamazaki et 
al., 2015) (Fig. 5a, green circles). As described in Table 1, increasing anthropogenic N loads can influence coral $\delta^{15} \mathrm{~N}$ in numerous ways and should change the CS- $\delta^{15} \mathrm{~N}$ of local corals.

For the GBR, anthropogenic changes in land use since the 1800's are thought to have increased the flow of terrestrial sediments (Lewis et al., 2007; McCulloch et al., 2003; Wooldridge et al., 2006) and N loads (Brodie et al., 2011; Devlin and Brodie, 2005; Furnas, 2003) into the coastal GBR lagoon. Chlorophyll and inorganic $\mathrm{N}$ concentrations in waters surrounding Magnetic Island are considered to be above eutrophication thresholds (Bell, 1992; Brodie et al., 2011; Wooldridge et al., 2006) as a result of increased riverine $\mathrm{N}$ input associated with flooding in the Burdekin River catchment (Brodie et al., 2007; Devlin and Brodie, 2005; Wooldridge et al., 2006). We were therefore surprised to find no discernible trend toward lower or higher $\mathrm{CS}-\delta^{15} \mathrm{~N}$ over the 168 year measurement period, this includes during periods of obvious impact from anthropogenic land-use change such as those associated with the introduction of sheep and cattle grazing to the Burdekin River catchment in1860 (Fig. 2e). Such land use changes are captured in the Mn and Y record of a coral skeleton collected in Geoffrey Bay, Magnetic Island (Fig. 2f; Lewis et al. (2007)) but do not cause a corresponding change in $\mathrm{CS}-\delta^{15} \mathrm{~N}$ in our core (Fig. 2a).

The lack of change in the Magnetic Island record could simply be due to low sensitivity of CS- $\delta^{15} \mathrm{~N}$ to $\mathrm{N}$ enrichment of the coral reef ecosystem. Yet in previous work we have found that subtle changes in the $\delta^{15} \mathrm{~N}$ of water column $\mathrm{N}$, or $\mathrm{N}$ availability, are recorded in $\mathrm{CS}-\delta^{15} \mathrm{~N}$ over relatively short spatial scales (Erler et al., 2015; Wang et al., 2015). Furthermore, numerous other studies have detected at least $2 \%$ changes in $\operatorname{CS}-\delta^{15} \mathrm{~N}$ as a result of anthropogenic $\mathrm{N}$ inputs (Marion et al., 2005; Yamazaki et al., 2015). Therefore significant $\mathrm{N}$ enrichment should result in observable shifts to $C S-\delta^{15} \mathrm{~N}$. Nevertheless, the magnitude of anthropogenic change required to cause a detectable change in $\mathrm{CS}-\delta^{15} \mathrm{~N}$ is unclear and probably varies among regions and environments. 
In order to establish the degree to which anthropogenic change would affect $C S-\delta^{15} \mathrm{~N}$, we compared the variability in the $\mathrm{CS}-\delta^{15} \mathrm{~N}$ from the Magnetic Island core with three cores from pristine reefs in the Northern section of the GBR. If the Magnetic Island CS- $\delta^{15} \mathrm{~N}$ record is indicative of eutrophication and its inherent variability, then we would expect it to be greater than the $\mathrm{CS}-\delta^{15} \mathrm{~N}$ variability in the Northern GBR records. However, we found no difference between the variance in the $C S-\delta^{15} \mathrm{~N}$ record from the Magnetic Island core and two of the three records from the pristine northern section of the GBR (Fig. 3).

The average CS- $\delta^{15} \mathrm{~N}$ in the three Northern GBR cores vary from one another by $\sim 1 \%$, possibly due to locally significant $\mathrm{N}$ contributions or productivity-driven $\mathrm{N}$ recycling efficiency differences among the corals (Wang et al., 2015). The average $C S-\delta^{15} \mathrm{~N}$ in the Magnetic Island coral is $<2 \%$ different from the three pristine Northern GBR cores throughout the entire sampling period, implying the Burdekin riverine $\mathrm{N}$ input/land use change did not change the $\mathrm{N}$ cycle in Magnetic Island waters significantly during the 168 year study period.

Further support of this interpretation comes from the $\delta^{15} \mathrm{~N}$ of shallow subsurface nitrate in the Coral Sea, which reflects the $\delta^{15} \mathrm{~N}$ of the supply of oceanic nitrate to the euphotic zone in the region. This nitrate $\delta^{15} \mathrm{~N}$ is $\sim 6 \%$ (Yoshikawa et al., 2015), such that the CS- $-\delta^{15} \mathrm{~N}$ of the Magnetic Island coral is roughly $1 \%$ higher. Similarly, CS- $\delta^{15} \mathrm{~N}$ from the reef margin of the island of Bermuda is $\sim 1 \%$ higher than the $\delta^{15} \mathrm{~N}$ of shallow subsurface nitrate in the Sargasso Sea (Wang et al., 2015). Since the mean $\delta^{15} \mathrm{~N}$ of plankton are observed to have a $\delta^{15} \mathrm{~N}$ similar to (or slightly higher than) the nitrate supply to the oligotrophic surface ocean (Montoya et al., 2002), the absolute value of the $\mathrm{CS}-\delta^{15} \mathrm{~N}$ in Bermuda coral are consistent with the coral feeding from an upper ocean $\mathrm{N}$ cycle fuelled with nitrate imported from below (Wang et al., 2015). Following the same logic, the absolute value of $C S-\delta^{15} \mathrm{~N}$ in the Magnetic Island coral is consistent with expectations if the open ocean is the dominant source of $\mathrm{N}$ to 
this region, which in turn suggests the riverine $\mathrm{N}$ input changes have not significantly altered the water column $\mathrm{N}$ cycle of Magnetic Island.

An alternative explanation for the lack of trend in the Magnetic Island CS- $\delta{ }^{15} \mathrm{~N}$ is that multiple changes to ecosystem $\mathrm{N}$ cycling could have had opposing effects on $\mathrm{CS}-\delta^{15} \mathrm{~N}$. As one scenario, an increase in the $\delta^{15} \mathrm{~N}$ of water column $\mathrm{N}$ associated with sewage discharge could increase phytoplankton abundance and reduce the mean trophic level of corals' food source, the latter tending to lower the $\delta^{15} \mathrm{~N}$ of the coral. Overall, such countering effects may yield a lack of change in $C S-\delta{ }^{15} \mathrm{~N}$. However, this alternative explanation relies not on only one coincidence but rather on many coincidences over the length of the record, as there have been multiple modifications of the Burdekin River catchment over the measurement period (Fig. 2e, f).

A third possibility is that the $\delta^{15} \mathrm{~N}$ of the riverine discharge is similar to the $\delta^{15} \mathrm{~N}$ of oceanic $\mathrm{N}$ supplied to the reefs. There are no direct $\delta^{15} \mathrm{~N}$ measurements in the Burdekin River, but the $\delta^{15} \mathrm{~N}$ of particulate organic matter from another anthropogenically affected system (the Pioneer River, $400 \mathrm{~km}$ south of the Burdekin River) is $\sim 9 \%$ (Jupiter et al., 2008), this is higher than the CS- $\delta^{15} \mathrm{~N}$ of the Magnetic Island coral and also the apparent oceanic nitrate supply to the GBR ( 6\%o ) (Yoshikawa et al., 2015). Bulk suspended particulate organic matter tends to have a low $\delta^{15} \mathrm{~N}$ relative to the other major $\mathrm{N}$ pools in both the open ocean and many coastal systems (Altabet, 1988; Erler et al., 2015; Knapp et al., 2011; Montoya et al., 2002). Speculatively, if the Burdekin riverine discharge has a similar particulate $\delta^{15} \mathrm{~N}$ signature to that of the Pioneer River, then we could expect that the total $\delta^{15} \mathrm{~N}$ for Burdekin riverine $\mathrm{N}$ input would be even higher than $9 \%$. As such the dominance of a stable $\mathrm{N}$ input from the Burdekin River to Magnetic Island is unlikely to explain the CS$\delta^{15} \mathrm{~N}$ record. Further, riverine discharge is strongly controlled by rainfall and catchment specific management, and the $\delta^{15} \mathrm{~N}$ of riverine discharge therefore is unlikely to be as stable 
as the $\delta^{15} \mathrm{~N}$ of oceanic $\mathrm{N}$, especially at seasonal timescales (i.e. our sampling resolution). Even if the annual average $\delta^{15} \mathrm{~N}$ of the Burdekin river discharge was similar to the $\delta^{15} \mathrm{~N}$ of oceanic $\mathrm{N}$, the reported changes in riverine $\mathrm{N}$ delivery to the region would still be expected to drive changes in the $\delta^{15} \mathrm{~N}$ of the $\mathrm{N}$ supply to the Magnetic Island reef, at least on seasonal timescales (Table 1).

It is also possible that acute changes in $\mathrm{CS}-\delta^{15} \mathrm{~N}$ could be obscured by the bi-annual sampling resolution. The drill holes used to collect coral powder samples were roughly $5 \mathrm{~mm}$ in diameter, for a coral growing $\sim 1.5 \mathrm{~cm}$ a year, this represents about 4 months of coral growth. Hence large and sudden (sub-annual time scale) swings in $\mathrm{CS}-\delta^{15} \mathrm{~N}$ may have been dampened in the record. However, if anthropogenic $\mathrm{N}$ input has significantly changed ecosystem N cycling since European settlement then we would expect to see changes in CS$\delta^{15} \mathrm{~N}$ on various time scales over the 168 year old record, or at least a higher variability in CS$\delta^{15} \mathrm{~N}$ relative to the Northern GBR cores. We did not observe either of these, suggesting that 1) $C S-\delta^{15} \mathrm{~N}$ has been stable over the 168 year measurement period, and 2) that apparent nutrient enrichment of the Magnetic Island reef waters has not been of significant magnitude to change ecosystem $\delta^{15} \mathrm{~N}$ or coral host/symbiont $\mathrm{N}$ cycling. If this is correct, and we must stress that we only have one coral core showing this stable temporal trend, then it directly contradicts past studies that indicate the region is suffering from declining water quality with respect to $\mathrm{N}$ enrichment.

The earliest measurements of water quality around Magnetic Island revealed concentrations of dissolved inorganic $\mathrm{N}$ and chlorophyll above the eutrophication thresholds estimated for other reef systems ( $1 \mu \mathrm{mol} \mathrm{L}$ and $0.4 \mu \mathrm{g} \mathrm{L}^{-1}$ respectively) (Bell, 1992; Muslim and Jones, 2003). Using measurements of coral tissue $\delta^{15} \mathrm{~N}$, Sammarco et al. (1999) suggested that Magnetic Island corals were affected by anthropogenic nutrient enrichment. However, despite all the presented evidence that Magnetic Island water quality is degraded, 
it is still unclear whether current concentrations of dissolved $\mathrm{N}$ and chlorophyll are elevated relative to historical values.

The stability of the Magnetic Island CS- $\delta^{15} \mathrm{~N}$ record indicates that regional $\mathrm{N}$ cycling has not changed significantly over the 168-year measurement period. This could be explained by the long term resilience of inshore coral reefs against anthropogenic change which has previously been documented by Perry et al. (2008). Furthermore, nutrient budget studies for the GBR show that, despite the fact that inshore regions receive significantly greater riverine loads, $\mathrm{N}$ accumulation is similar between inshore and offshore regions (Furnas et al., 2011). It has been suggested that high rates of mineralisation and denitrification in coastal areas prevents $\mathrm{N}$ accumulation (Alongi and McKinnon, 2005; Alongi et al., 2007), and thus stabilizes regional ecosystem $\mathrm{N}$ dynamics. The CS- $\delta^{15} \mathrm{~N}$ record from the Magnetic Island coral core suggests that ecosystem $\mathrm{N}$ dynamics have been largely stable over the168 year measurement period on this particular reef. This may be due to the ability of the ecosystem to attenuate anthropogenic $\mathrm{N}$.

Nevertheless, this finding is qualitatively different from most other studies of coastal coral reef benthic organism $\delta^{15} \mathrm{~N}$ (Fig. 5). For instance Risk et al. (2009b) showed a 3\%o increase in the $\delta^{15} \mathrm{~N}$ of proteinaceous coral skeleton material as a result of urbanisation and sewage discharge (Fig. 5b, red symbols), whereas Baker et al. (2010b) observed a long term decrease in the $\delta^{15} \mathrm{~N}$ of octocoral skeletons as a result of increasing fertilizer usage (Fig. 5b, light blue symbols). Moreover, previous $\mathrm{CS}-\delta^{15} \mathrm{~N}$ measurements from boulder forming hard corals show great temporal variability, which the authors linked to anthropogenic activity (Fig. 5a). In contrast, our study shows a prolonged stability of CS- $\delta^{15} \mathrm{~N}$ and suggests that some inshore reef systems are more resilient to anthropogenic $\mathrm{N}$ input than previously thought. 
While we do not observe any clear long-term changes in the $\mathrm{CS}-\delta^{15} \mathrm{~N}$ of the Magnetic Island core, we observe periods of lower $\mathrm{CS}-\delta^{15} \mathrm{~N}$ in the latter half of the record that may well be attributable to anthropogenic change. While there was no clear relationship between CS$\delta^{15} \mathrm{~N}$ and $\delta^{18} \mathrm{O}$ in the Magnetic Island core, perhaps because the $\delta^{18} \mathrm{O}$ of coral skeletal material responds to both temperature and salinity, the minima in $\mathrm{CS}-\delta^{15} \mathrm{~N}$ for the Magnetic Island core appear linked to high runoff events in the nearby catchment during wet periods starting in the 1930s (Fig. 2a,b). This is supported by previous studies showing that Burdekin River runoff is clearly detected in Magnetic Island corals (Cantin and Lough, 2014; Lewis et al., 2007). Studies of flood plume nutrient transport show that much of the particulate $\mathrm{N}$ discharged from the Burdekin River is deposited within $10 \mathrm{~km}$ of the river mouth (Bainbridge et al., 2012). However inorganic N, including that derived from terrestrial fertiliser runoff as well as nutrients generated from remineralisation of settled particulates, is known to reach Magnetic Island and beyond (Bainbridge et al., 2012). It is not clear whether the CS- $\delta{ }^{15} \mathrm{~N}$ minima observed in the Magnetic Island core are the result of increased fertiliser usage since 1930 (Furnas, 2003; Pulsford, 1993), or perhaps the result of phosphorus driven changes in N fixation (Bell et al., 1999). Nevertheless, the $\mathrm{CS}-\delta^{15} \mathrm{~N}$ changes are minor and do not remain depressed beyond the periods of high rainfall.

Evidence to date appears to show that the growth rate of inshore corals in the GBR, monitored here by the linear extension rate (LER), has been relatively stable up until 1990 (Cooper et al., 2008; De'ath et al., 2009). For the Magnetic Island core, the decreases in CS$\delta^{15} \mathrm{~N}$ that accompany large rainfall events after 1930 were not correlated with any change in linear extension (Fig. 2c). Hence the biogeochemical changes reflected by the post-1930 minima in $\mathrm{CS}-\delta^{15} \mathrm{~N}$ do not appear to have influenced the linear extension of the studied Porites corals from Magnetic Island. Two large thermal bleaching events after 1990 did reduce calcification by up to $13 \%$ relative to baseline rates, but with good recovery in coral 
growth following the bleaching events (Cantin and Lough, 2014). Cantin and Lough (2014) argue that the post-bleaching recovery of the Magnetic Island corals is evidence that the reefs are not suffering from local anthropogenic impacts and that inshore reefs are more resilient to anthropogenic change than previously thought, a view supported by our CS- $\delta^{15} \mathrm{~N}$ record. At face value, the bleaching events after 1990 also raise the possibility that ongoing environmental changes on Magnetic Island reefs may have reached the point where the corals are now vulnerable. The measured increase in $\mathrm{CS}-\delta^{15} \mathrm{~N}$ from the Magnetic Island core after 1980 (Fig. 3) may be a sign that cumulative anthropogenic changes are beginning to alter ecosystem $\delta^{15} \mathrm{~N}$ beyond the historical norm. These speculations await measurement of CS$\delta^{15} \mathrm{~N}$ from Magnetic Island coral skeletons produced after 1987 and comparison with $\mathrm{CS}-\delta^{15} \mathrm{~N}$ from other inshore reef systems.

\subsection{Conclusions}

In this study we have used a new and highly precise method to reconstruct one of the longest, most highly resolved, continuous records of tropical hard coral skeleton $\mathrm{N}$ isotopic content. This record reveals a remarkable stability in the $\mathrm{N}$ cycle of an inshore coastal reef over 168 years, contrary to most other temporal hard coral $\delta^{15} \mathrm{~N}$ reconstructions. Using a new approach we have also measured the isotopic content of foreign organic $\mathrm{N}$ trapped within a hard coral skeleton, finding that this material has become ${ }^{15} \mathrm{~N}$ enriched over the 1900 's and possibly tracking anthropogenic changes in the composition of continental runoff. Now that we have established the robustness of our $\operatorname{CS}-\delta^{15} \mathrm{~N}$ technique, the challenge is to determine if the observed resilience to anthropogenic $\mathrm{N}$ discharge on the studied reef system continues beyond 1990, and to establish if similar CS- $\delta^{15} \mathrm{~N}$ stability exists for other coastal reef systems within the GBR. 


\section{References}

Alongi, D.M., McKinnon, A.D., 2005. The cycling and fate of terrestrially-derived sediments and nutrients in the coastal zone of the Great Barrier Reef shelf. Mar Pollut Bull 51, 239-252.

Alongi, D.M., Trott, L.A., Pfitzner, J., 2007. Deposition, mineralization, and storage of carbon and nitrogen in sediments of the far northern and northern Great Barrier Reef shelf. Cont. Shelf Res. 27, 2595-2622.

Altabet, M., 1988. Variations in nitrogen isotopic composition between sinking and suspended particles: Implications for nitrogen cycling and particle transformation in the open ocean. Deep Sea Research Part A. Oceanographic Research Papers 35, 535554.

Bainbridge, Z.T., Wolanski, E., Álvarez-Romero, J.G., Lewis, S.E., Brodie, J.E., 2012. Fine sediment and nutrient dynamics related to particle size and floc formation in a Burdekin River flood plume, Australia. Mar Pollut Bull 65, 236-248.

Baker, D.M., Jordan-Dahlgren, E., Angel Maldonado, M., Harvell, C.D., 2010a. Sea fan corals provide a stable isotope baseline for assessing sewage pollution in the Mexican Caribbean. Limnol. Oceanogr. 55, 2139-2149.

Baker, D.M., Webster, K.L., Kim, K., 2010b. Caribbean octocorals record changing carbon and nitrogen sources from 1862 to 2005. Global Change Biology 16, 2701-2710.

Barnes, D., Taylor, R., 2001. On the nature and causes of luminescent lines and bands in coral skeletons. Coral Reefs 19, 221-230.

Barnes, D., Taylor, R., 2005. On the nature and causes of luminescent lines and bands in coral skeletons: II. Contribution of skeletal crystals. J Exp Mar Biol Ecol 322, 135142.

Bell, P., 1992. Eutrophication and coral reefs-some examples in the Great Barrier Reef lagoon. Water Res. 26, 553-568.

Bell, P., Elmetri, I., Uwins, P., 1999. Nitrogen fixation by Trichodesmium spp. in the Central and Northern Great Barrier Reef Lagoon: relative importance of the fixed-nitrogen load. Marine ecology. Progress series 186, 119-126.

Bell, P.R.F., Elmetri, I., 1995. Ecological indicators of large-scale eutrophication in the Great Barrier Reef lagoon. Ambio 24, 208-215.

Bessell-Browne, P., Stat, M., Thomson, D., Clode, P.L., 2014. Coscinaraea marshae corals that have survived prolonged bleaching exhibit signs of increased heterotrophic feeding. Coral Reefs, 1-10.

Boto, K., Isdale, P., 1985. Fluorescent bands in massive corals result from terrestrial fulvic acid inputs to nearshore zone. Nature 315, 396-397.

Breitenbach, S.F., Bernasconi, S.M., 2011. Carbon and oxygen isotope analysis of small carbonate samples (20 to $100 \mu \mathrm{g}$ ) with a GasBench II preparation device. Rapid Commun. Mass Sp. 25, 1910-1914.

Brodie, J., De'Ath, G., Devlin, M., Furnas, M., Wright, M., 2007. Spatial and temporal patterns of near-surface chlorophyll a in the Great Barrier Reef lagoon. Marine and Freshwater Research 58, 342-353.

Brodie, J., Devlin, M., Haynes, D., Waterhouse, J., 2011. Assessment of the eutrophication status of the Great Barrier Reef lagoon (Australia). Biogeochemistry 106, 281-302.

Cantin, N.E., Lough, J.M., 2014. Surviving Coral Bleaching Events: <italic>Porites</italic> Growth Anomalies on the Great Barrier Reef. PLoS ONE 9, e88720. 
Carpenter, S.R., Caraco, N.F., Correll, D.L., Howarth, R.W., Sharpley, A.N., Smith, V.H., 1998. Nonpoint pollution of surface waters with phosphorus and nitrogen. Ecol. Appl. $8,559-568$.

Cooper, T.F., De 'ath, G., Fabricius, K.E., Lough, J.M., 2008. Declining coral calcification in massive Porites in two nearshore regions of the northern Great Barrier Reef. Global Change Biology 14, 529-538.

Costanzo, S.D., O'Donohue, M.J., Dennison, W.C., Loneragan, N.R., Thomas, M., 2001. A new approach for detecting and mapping sewage impacts. Mar Pollut Bull 42, 149156.

Dailer, M.L., Knox, R.S., Smith, J.E., Napier, M., Smith, C.M., 2010. Using delta N-15 values in algal tissue to map locations and potential sources of anthropogenic nutrient inputs on the island of Maui, Hawai'i, USA. Mar Pollut Bull 60, 655-671.

De'ath, G., Lough, J.M., Fabricius, K.E., 2009. Declining coral calcification on the Great Barrier Reef. Science 323, 116-119.

De'ath, G., Fabricius, K.E., Sweatman, H., Puotinen, M., 2012. The 27-year decline of coral cover on the Great Barrier Reef and its causes. P Natl Acad Sci USA 109, 1799517999.

Devlin, M.J., Brodie, J., 2005. Terrestrial discharge into the Great Barrier Reef Lagoon: nutrient behavior in coastal waters. Mar Pollut Bull 51, 9-22.

Elser, J.J., Bracken, M.E.S., Cleland, E.E., Gruner, D.S., Harpole, W.S., Hillebrand, H., Ngai, J.T., Seabloom, E.W., Shurin, J.B., Smith, J.E., 2007. Global analysis of nitrogen and phosphorus limitation of primary producers in freshwater, marine and terrestrial ecosystems. Ecology Letters 10, 1135-1142.

Erler, D.V., Wang, X.T., Sigman, D.M., Scheffers, S., Shepherd, B.O., 2015. Controls on the nitrogen isotopic composition of shallow water corals across a tropical reef flat transect Coral Reefs 34, 329-338.

Fabricius, K., De'ath, G., McCook, L., Turak, E., Williams, D.M., 2005. Changes in algal, coral and fish assemblages along water quality gradients on the inshore Great Barrier Reef. Mar Pollut Bull 51, 384-398.

Fowler, D., Coyle, M., Skiba, U., Sutton, M.A., Cape, J.N., Reis, S., Sheppard, L.J., Jenkins, A., Grizzetti, B., Galloway, J.N., Vitousek, P., Leach, A., Bouwman, A.F., Butterbach-Bahl, K., Dentener, F., Stevenson, D., Amann, M., Voss, M., 2013. The global nitrogen cycle in the twenty-first century. Philos T Roy Soc B 368, 20130164.

Furnas, M., 2003. Corals and catchments-terrestrial runoff to the Great Barrier Reef. . Australian Institute of Marine Science,Townsville, Australia.

Furnas, M., Alongi, D., McKinnon, D., Trott, L., Skuza, M., 2011. Regional-scale nitrogen and phosphorus budgets for the northern $\left(14^{\circ} \mathrm{S}\right)$ and central $\left(17^{\circ} \mathrm{S}\right)$ Great Barrier Reef sheld ecosystem. Cont. Shelf Res. 31, 1967-1990.

Furnas, M., Mitchell, A., Skuza, M., Brodie, J., 2005. The other 90\%: phytoplankton responses to enhanced nutrient availability in the Great Barrier Reef Lagoon. Mar Pollut Bull 51, 253-265.

Grove, C.A., Nagtegaal, R., Zinke, J., Scheufen, T., Koster, B., Kasper, S., McCulloch, M.T., van den Bergh, G., Brummer, G.J.A., 2010. River runoff reconstructions from novel spectral luminescence scanning of massive coral skeletons. Coral Reefs 29, 579-591.

Hayes, J.M., 1983. Practice and principles of isotopic measurements in organic geochemistry. Organic geochemistry of contemporaneous and ancient sediments 5, e5.

Heikoop, J., Risk, M., Lazier, A., Edinger, E., Jompa, J., Limmon, G., Dunn, J., Browne, D., Schwarcz, H., 2000. Nitrogen-15 signals of anthropogenic nutrient loading in reef corals. Mar Pollut Bull 40, 628-636. 
Heikoop, J.M., Dunn, J.J., Risk, M.J., Sandeman, I.M., Schwarcz, H.P., Waltho, N., 1998. Relationship between light and the $\delta 15 \mathrm{~N}$ of coral tissue: examples from Jamaica and Zanzibar. Limnol. Oceanogr. 43, 909-920.

Hobbie, E.A., Ouimette, A.P., 2009. Controls of nitrogen isotope patterns in soil profiles. Biogeochemistry 95, 355-371.

Hoegh-Guldberg, O., Muscatine, L., Goiran, C., Siggaard, D., Marion, G., 2004. Nutrientinduced perturbations to delta $\mathrm{C}-13$ and delta $\mathrm{N}-15$ in symbiotic dinoflagellates and their coral hosts. Mar. Ecol-Prog. Ser. 280, 105-114.

Huygens, D., Denef, K., Vandeweyer, R., Godoy, R., Van Cleemput, O., Boeckx, P., 2008. Do nitrogen isotope patterns reflect microbial colonization of soil organic matter fractions? Biology and Fertility of Soils 44, 955-964.

Isdale, P., 1984. Fluorescent bands in massive corals record centuries of coastal rainfall. Nature 310, 578-579.

Jupiter, S., Roff, G., Marion, G., Henderson, M., Schrameyer, V., McCulloch, M., HoeghGuldberg, O., 2008. Linkages between coral assemblages and coral proxies of terrestrial exposure along a cross-shelf gradient on the southern Great Barrier Reef. Coral Reefs 27, 887-903.

Kendall, C., Elliot, E.M., Wankel, S.D., 2007. Stable Isotopes in Ecology and Environmental Science. Blackwell Publishing.

Kerley, S.J., Jarvis, S.C., 1997. Variation in N-15 natural abundance of soil, humic fractions and plant materials in a disturbed and an undisturbed grassland. Biology and Fertility of Soils 24, 147-152.

Knapp, A.N., Sigman, D.M., Lipschultz, F., Kustka, A.B., Capone, D.G., 2011. Interbasin isotopic correspondence between upper-ocean bulk DON and subsurface nitrate and its implications for marine nitrogen cycling. Global Biogeochem Cy 25.

Koop, K., Booth, D., Broadbent, A., Brodie, J., Bucher, D., Capone, D., Coll, J., Dennison, W., Erdmann, M., Harrison, P., Hoegh-Guldberg, O., Hutchings, P., Jones, G.B., Larkum, A.W.D., O'Neil, J., Steven, A., Tentori, E., Ward, S., Williamson, J., Yellowlees, D., 2001. ENCORE: The effect of nutrient enrichment on coral reefs. Synthesis of results and conclusions. Mar Pollut Bull 42, 91-120.

Kroon, F.J., Kuhnert, P.M., Henderson, B.L., Wilkinson, S.N., Kinsey-Henderson, A., Abbott, B., Brodie, J.E., Turner, R.D., 2012. River loads of suspended solids, nitrogen, phosphorus and herbicides delivered to the Great Barrier Reef lagoon. Mar Pollut Bull 65, 167-181.

Lapointe, B.E., Langton, R., Bedford, B.J., Potts, A.C., Day, O., Hu, C., 2010. Land-based nutrient enrichment of the Buccoo Reef Complex and fringing coral reefs of Tobago, West Indies. Mar Pollut Bull 60, 334-343.

Lewis, S.E., Brodie, J.E., McCulloch, M.T., Mallela, J., Jupiter, S.D., Stuart Williams, H., Lough, J.M., Matson, E.G., 2012. An assessment of an environmental gradient using coral geochemical records, Whitsunday Islands, Great Barrier Reef, Australia. Mar Pollut Bull 65, 306-319.

Lewis, S.E., Shields, G.A., Kamber, B.S., Lough, J.M., 2007. A multi-trace element coral record of land-use changes in the Burdekin River catchment, NE Australia. Palaeogeography Palaeoclimatology Palaeoecology 246, 471-487.

Llewellyn, L.E., Everingham, Y.L., Lough, J.M., 2012. Pharmacokinetic modelling of multidecadal luminescence time series in coral skeletons. Geochim. Cosmochim. Ac. 83, 263-271.

Lough, J.M., 2007. Tropical river flow and rainfall reconstructions from coral luminescence: Great Barrier Reef, Australia. Paleoceanography 22, PA2218. 
Lough, J.M., 2011. Measured coral luminescence as a freshwater proxy: comparison with visual indices and a potential age artefact. Coral Reefs 30, 169-182.

Marion, G.S., Dunbar, R.B., Mucciarone, D.A., Kremer, J.N., Lansing, J.S., Arthawiguna, A., 2005. Coral skeletal $\delta^{15} \mathrm{~N}$ reveals isotopic traces of an agricultural revolution. Mar Pollut Bull 50, 931-944.

McClelland, J.W., Montoya, J.P., 2002. Trophic relationships and the nitrogen isotopic composition of amino acids in plankton. Ecology 83, 2173-2180.

McCulloch, M., Fallon, S., Wyndham, T., Hendy, E., Lough, J., Barnes, D., 2003. Coral record of increased sediment flux to the inner Great Barrier Reef since European settlement. Nature 421, 727-730.

Michener, R.H., Kaufman, L., 2007. Stable isotope ratios as tracers in marine food webs: an update, in: Michener, R.H., Lajtha, K. (Eds.), Stable isotopes in ecology and environmental science. Blackwell Publishing.

Montoya, J.P., Carpenter, E.J., Capone, D.G., 2002. Nitrogen fixation and nitrogen isotope abundances in zooplankton of the oligotrophic North Atlantic. Limnol. Oceanogr. 47, 1617-1628.

Muscatine, L., Goiran, C., Land, L., Jaubert, J., Cuif, J.P., Allemand, D., 2005. Stable isotopes (delta C-13 and delta N-15) of organic matrix from coral skeleton. P. Natl. Acad. Sci. USA. 102, 1525-1530.

Muslim, I., Jones, G., 2003. The seasonal variation of dissolved nutrients, chlorophyll a and suspended sediments at Nelly Bay, Magnetic Island. Estuar. Coast. Shelf S. 57, 445455.

Perry, C.T., Smithers, S.G., Palmer, S., Larcombe, P., Johnson, K., 2008. 1200 year paleoecological record of coral community development from the terrigenous inner shelf of the Great Barrier Reef. Geology 36, 691-694.

Prouty, N.G., Roark, E.B., Koenig, A.E., Demopoulos, A.W.J., Batista, F.C., Kocar, B.D., Selby, D., McCarthy, M.D., Mienis, F., 2014. Deep-sea coral record of humanimpact on watershed quality in the Mississippi River Basin. Global Biogeochem Cy 28, 2943.

Pulsford, J., 1993. Historical nutrient usage in coastal Queensland river catchments adjacent to the Great Barrier Reef Marine Park. Research publication.

Ramos-Silva, P., Marin, F., Kaandorp, J., Marie, B., 2013. Biomineralization toolkit: The importance of sample cleaning prior to the characterization of biomineral proteomes. P Natl Acad Sci USA 110, E2144-E2146.

Reynaud, S., Martinez, P., Houlbreque, F., Billy, I., Allemand, D., Ferrier-Pages, C., 2009. Effect of light and feeding on the nitrogen isotopic composition of a zooxanthellate coral: role of nitrogen recycling. Mar. Ecol-Prog. Ser. 392, 103-110.

Risk, M.J., Lapointe, B.E., Sherwood, O.A., Bedford, B.J., 2009a. The use of delta N-15 in assessing sewage stress on coral reefs. Mar Pollut Bull 58, 793-802.

Risk, M.J., Sherwood, O.A., Nairn, R., Gibbons, C., 2009b. Tracking the record of sewage discharge off Jeddah, Saudi Arabia, since 1950, using stable isotope records from antipatharians. Mar. Ecol-Prog. Ser. 397, 219-226.

Sammarco, P., Risk, M., Schwarcz, H., Heikoop, J., 1999. Cross-continental shelf trends in coral $\delta 15 \mathrm{~N}$ on the Great Barrier Reef: further consideration of the reef nutrient paradox. Marine ecology. Progress series 180, 131-138.

Sherwood, O.A., Guilderson, T.P., Batista, F.C., Schiff, J.T., McCarthy, M.D., 2014. Increasing subtropical North Pacific Ocean nitrogen fixation since the Little Ice Age. Nature 505, 78-+. 
Sherwood, O.A., Heikoop, J.M., Scott, D.B., Risk, M.J., Guilderson, T.P., McKinney, R.A., 2005. Stable isotopic composition of deep-sea gorgonian corals Primnoa spp.: a new archive of surface processes. Mar. Ecol-Prog. Ser. 301, 135-148.

Sherwood, O.A., Lapointe, B.E., Risk, M.J., Jamieson, R.E., 2010. Nitrogen isotopic records of terrestrial pollution encoded in floridian and bahamian gorgonian corals. Environ. Sci. Technol. 44, 874-880.

Sherwood, O.A., Lehmann, M.F., Schubert, C.J., Scott, D.B., McCarthy, M.D., 2011. Nutrient regime shift in the western North Atlantic indicated by compound-specific delta N-15 of deep-sea gorgonian corals. P. Natl. Acad. Sci. USA. 108, 1011-1015.

Sherwood, O.A., Thresher, R.E., Fallon, S.J., Davies, D.M., Trull, T.W., 2009. Multi-century time-series of N-15 and C-14 in bamboo corals from deep Tasmanian seamounts: evidence for stable oceanographic conditions. Mar. Ecol-Prog. Ser. 397, 209-218.

Sigman, D.M., Casciotti, K.L., Andreani, M., Barford, C., Galanter, M., Bohlke, J.K., 2001. A bacterial method for the nitrogen isotopic analysis of nitrate in seawater and freshwater. Anal. Chem. 73, 4145-4153.

Susic, M., Boto, K., Isdale, P., 1991. Fluorescent humic acid bands in coral skeletons originate from terrestrial runoff. Mar. Chem. 33, 91-104.

Titlyanov, E.A., Kiyashko, S.I., Titlyanova, T.V., Kalita, T.L., Raven, J.A., 2008. delta(13)C and delta(15)N values in reef corals Porites lutea and P-cylindrica and in their epilithic and endolithic algae. Mar. Biol. 155, 353-361.

Wang, X.T., Sigman, D.M., Cohen, A.L., Sinclair, D.J., Sherrell, R.M., Weigand, M.A., Erler , D.V., Ren, H., 2015. Isotopic composition of skeleton-bound organic nitrogen in reef-building symbiotic corals: a new method and proxy evaluation at Bermuda. Geochim. Cosmochim. Ac. 148, 179-190.

Ward-Paige, C.A., Risk, M.J., Sherwood, O.A., 2005. Reconstruction of nitrogen sources on coral reefs: delta N-15 and delta C-13 in gorgonians from Florida Reef Tract. Mar. Ecol-Prog. Ser. 296, 155-163.

Williams, B., Grottoli, A.G., 2010. Stable nitrogen and carbon isotope (delta N-15 and delta C-13) variability in shallow tropical Pacific soft coral and black coral taxa and implications for paleoceanographic reconstructions. Geochim. Cosmochim. Ac. 74, 5280-5288.

Wooldridge, S., Brodie, J., Furnas, M., 2006. Exposure of inner-shelf reefs to nutrient enriched runoff entering the Great Barrier Reef Lagoon: Post-European changes and the design of water quality targets. Mar Pollut Bull 52, 1467-1479.

Yamazaki, A., Watanabe, T., Takahata, N., Sano, Y., Tsunogai, U., 2013. Nitrogen isotopes in intra-crystal coralline aragonites. Chem.Geol. 351, 276-280.

Yamazaki, A., Watanabe, T., Tsunogai, U., 2011. Nitrogen isotopes of organic nitrogen in reef coral skeletons as a proxy of tropical nutrient dynamics. Geophys. Res. Lett. 38, L19605.

Yamazaki, A., Watanabe, T., Tsunogai, U., Hasegawa, H., Yamano, H., 2015. The coral $\delta 15 \mathrm{~N}$ record of terrestrial nitrate loading varies with river catchment land use. Coral Reefs 34, 353-362.

Yoshikawa, C., Makabe, A., Shiozaki, T., Toyoda, S., Yoshida, O., Furuya, K., Yoshida, N., 2015. Nitrogen isotope ratios of nitrate and $N^{*}$ anomalies in the subtropical South Pacific. Geochemistry, Geophysics, Geosystems. 


\section{Acknowledgements}

This work was funded by Southern Cross University (Special Studies Leave program), the Australian Research Council (LP100200732 to DVE), US NSF grants OCE-1234664 and OCE-1060947 (to DMS), the Schlanger Ocean Drilling Fellowship Program (to XTW), and the Grand Challenges Program at Princeton University (to DMS). We thank G. Jones for the coral core and M. Weigand for technical assistance. 


\section{Tables}

Table 1. The expected influences of anthropogenic changes to coastal reef $\mathrm{N}$ supply and $\mathrm{N}$ cycling on the CS- $\delta^{15} \mathrm{~N}$ of resident Porites corals (DIN is dissolved inorganic N and PON is particulate organic $\mathrm{N}$ )

\begin{tabular}{|c|c|}
\hline Anthropogenic change & Effect on $C S-\delta^{15} \mathrm{~N}$ \\
\hline $\begin{array}{l}\text { Shift in the } \delta^{15} \mathrm{~N} \text { of source DIN and } \\
\text { PON to reefs }\end{array}$ & $\begin{array}{l}\text { Uptake of DIN by zooxanthellae, uptake of DIN by microbes } \\
\text { which are then consumed by the coral, or direct consumption of } \\
\text { PON, all change CS- } \delta^{15} \mathrm{~N} \text { in the direction of the } \delta^{15} \mathrm{~N} \text { shift } \\
\text { (Erler et al., 2015; Hoegh-Guldberg et al., 2004; Wang et al., } \\
2015 \text { ) }\end{array}$ \\
\hline Increase in DIN supply & $\begin{array}{l}\text { Increase in phytoplankton abundance and corresponding trophic } \\
\text { level changes in } \delta^{15} \mathrm{~N} \text { are recorded in } \mathrm{CS}-\delta^{15} \mathrm{~N} \text { (Sherwood et al., } \\
\text { 2011) }\end{array}$ \\
\hline $\begin{array}{l}\text { Increase in PON (coral food } \\
\text { source) supply }\end{array}$ & $\begin{array}{l}\text { Changes in } \mathrm{N} \text { recycling efficiency and increased ammonium } \\
\text { leakage increases } \mathrm{CS}-\delta^{15} \mathrm{~N} \text { (Wang et al., 2015) }\end{array}$ \\
\hline Increase in turbidity & $\begin{array}{l}\text { Decreased zooxanthellae activity, less DIN uptake and lowering } \\
\text { of CS- } \delta{ }^{15} \mathrm{~N} \text { (Heikoop et al., 1998) }\end{array}$ \\
\hline Sedimentation & $\begin{array}{l}\text { Reduced zooxanthellae numbers, possible bleaching and } \\
\text { increased CS- } \delta{ }^{15} \mathrm{~N} \text { (Bessell-Browne et al., 2014) }\end{array}$ \\
\hline
\end{tabular}




\section{Figure Legends}

Figure 1. Map of the coral core collection sites in relation to the Australian mainland and the Burdekin River. One core was collected from Geoffrey Bay, Magnetic Island $\left(19.15^{\circ} \mathrm{S}\right.$, $146.87^{\circ} \mathrm{E}$ ) in 1987 , while three other cores were collected in the far northern section of the GBR in 1990.

Figure 2. (a) Annual CS- $\delta^{15} \mathrm{~N}(\%) \pm \mathrm{SD}(1 \sigma)$ of a 168 year old Porites coral core from Magnetic Island in the GBR, 5 year Gaussian filtered data and the average CS- $\delta^{15} \mathrm{~N}$ for the period 1820 - 1840 (grey line) are also shown. (b) Reconstructed Burdekin River discharge between 1820 and 1987 (Lough, 2007) and instrumental Burdekin River discharge between 1920 and 1987 (5 Gaussian filtered). (c) Annual $\delta^{18} \mathrm{O}$ (\%o) (Gaussian filtered, 5 years) and average $\delta^{18} \mathrm{O}$ for the period 1820 to 1840 (grey line). (d) Linear extension rates $(\mathrm{cm})$ (Gaussian filtered, 5years) and average LER for the period 1820 to 1840. (e) Sheep and cattle numbers (millions) in the Burdekin River catchment between 1820 and 1987, data from Lewis et al. (2007). (f) Concentrations of Mn (ppm) and Y (ppb) in a Magnetic Island coral core between 1820 and 1987, data from Lewis et al. (2007).

Figure 3. Plot of annual mean CS- $\delta^{15} \mathrm{~N}( \pm \mathrm{SD})$ for the three northern GBR corals (NR1, NR2 and NR3) the complete Magnetic Island coral core (Mag. Isl. complete), the Magnetic Island coral before 1980 (Mag. Isl. <1980) and the Magnetic Island coral core after 1980 (Mag. Isl. >1980). The ages of the northern GBR cores were 1974 - 1990, $1973-1990$ and $1975-$ 1990 for NR1, NR2 and NR3 respectively. Records with a statistically similar annual mean 
$\mathrm{CS}-\delta^{15} \mathrm{~N}$ share capital letters while records with a statistically similar variance share lowercase letters. The significance level is 0.05 . The values are the actual mean yearly $C S-\delta^{15} \mathrm{~N}$ values for each record.

Figure 4. (a) The $\delta^{15} \mathrm{~N}(\%)$ of cleaned and uncleaned coral skeleton powders, as well as the calculated $\delta^{15} \mathrm{~N}$ of the foreign organic nitrogen (FON), in 40 of the most conspicuous luminescent bands from the Magnetic Island coral core. The FON- $\delta^{15} \mathrm{~N}$ is the difference between cleaned and uncleaned powders corrected for $\mathrm{N}$ content, see equation (1) in text. Cleaned $\delta^{15} \mathrm{~N}$ is the same as $\mathrm{CS}-\delta^{15} \mathrm{~N}$. The lines are the linear regressions of the three parameters with the regression coefficients presented in the legend, black $=$ cleaned $\delta^{15} \mathrm{~N}\left(\mathrm{R}^{2}\right.$ $\sim 0$, not shown in legend $)$, blue $=$ uncleaned $\delta^{15} \mathrm{~N}\left(\mathrm{R}^{2}=0.49\right)$, red $=\mathrm{FON}-\delta^{15} \mathrm{~N}\left(\mathrm{R}^{2}=0.58\right)$. Error bars for the cleaned and uncleaned powders are SD $(1 \sigma)$ calculated for every $4^{\text {th }}$ luminescent band, and for the $\mathrm{FON}-\delta^{15} \mathrm{~N}$ the error bars are the propagated errors calculated according to Hayes (1983). (b) The nitrogen content $\left(\mu \mathrm{mol} \mathrm{N} \mathrm{g}{ }^{-1}\right) \pm \operatorname{SD}(1 \sigma)$ of the cleaned coral skeletal powder and the calculated FON content (i.e. the difference between the $\mathrm{N}$ content of uncleaned and cleaned skeletal powders).

Figure 5. (a) Comparison of published temporal $\mathrm{CS}-\delta^{15} \mathrm{~N}$ records derived from boulder forming hard coral cores with the Magnetic Island record. Records are from Keswick (GBR) Island (Jupiter et al., 2008), Whitsunday Islands (GBR) (Lewis et al., 2012), Bali (Marion et al., 2005), and Ryuku Islands (Yamazaki et al., 2015). (b) Comparison of $\mathrm{CS}-\delta^{15} \mathrm{~N}$ from this study with published proteinaceous coral skeletal $\delta^{15} \mathrm{~N}$ records. Records are from the Caribbean (Baker et al., 2010b), Jeddah (Risk et al., 2009b), Florida (Ward-Paige et al., 2005), Mexico (Baker et al., 2010a), Gulf of Mexico (Prouty et al., 2014), Hawaii (Sherwood 
et al., 2014), Nova Scotia ${ }^{a}$ (Sherwood et al., 2011), Nova Scotia ${ }^{b}$ (Sherwood et al., 2005), Tasmania (Sherwood et al., 2009), and the S.E coast of the USA (Williams and Grottoli, 2010). 


\section{Figures}

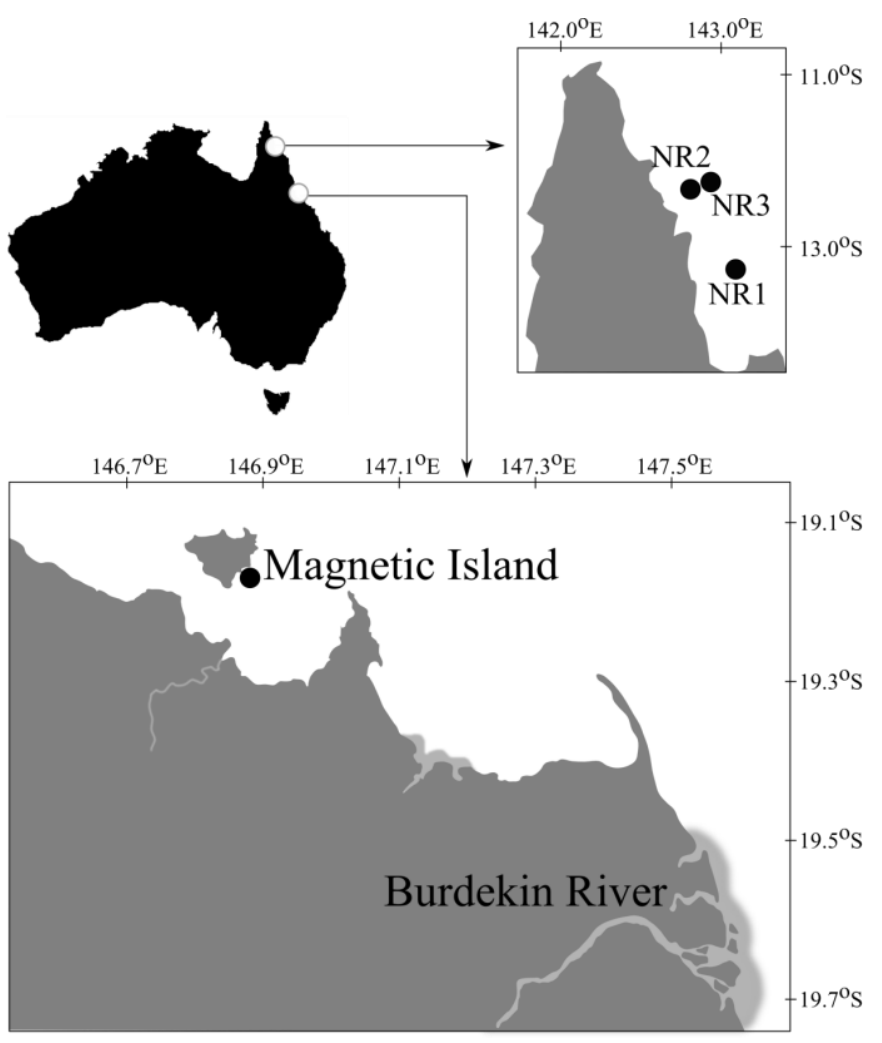

Figure 1 


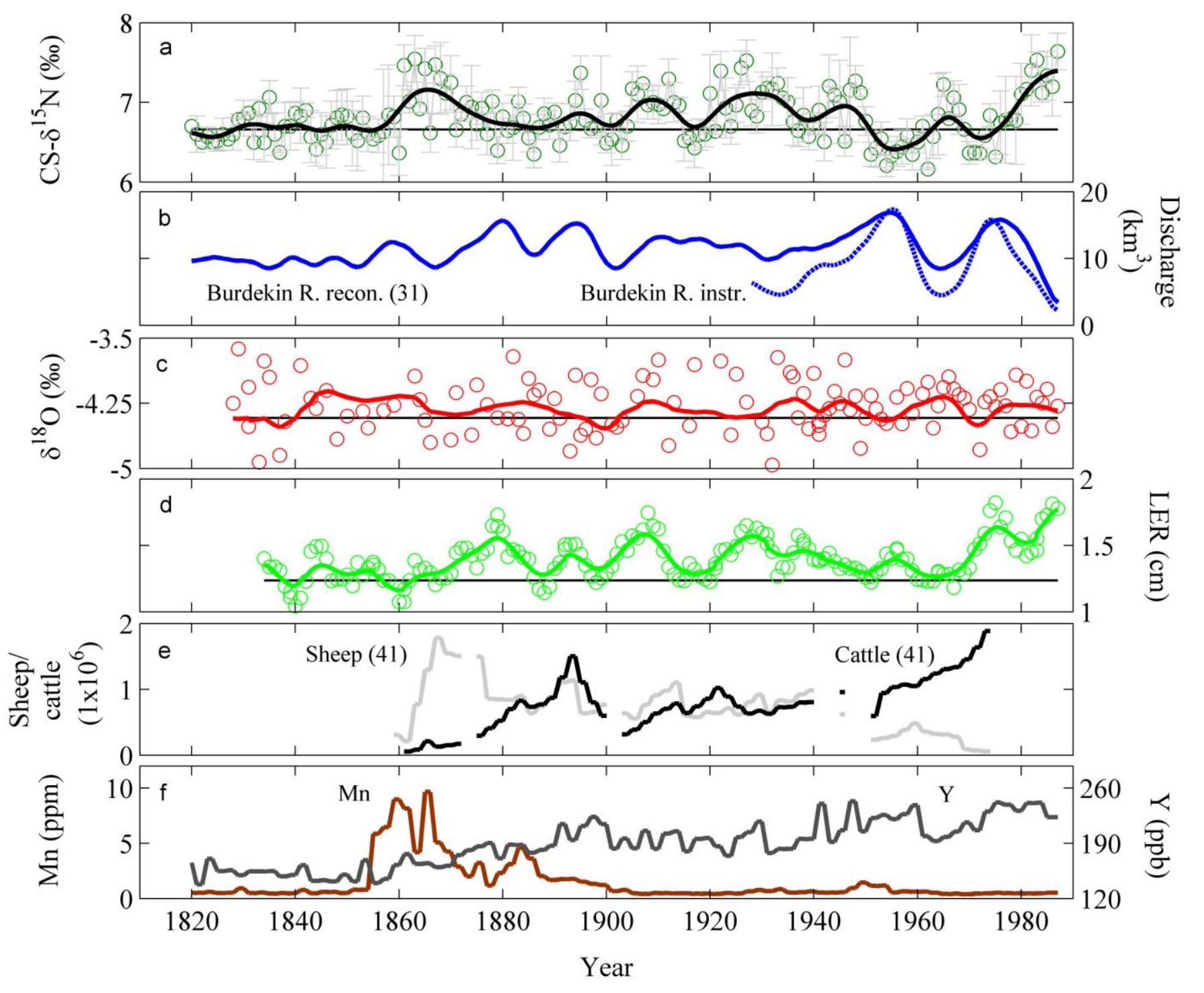

Figure 2 


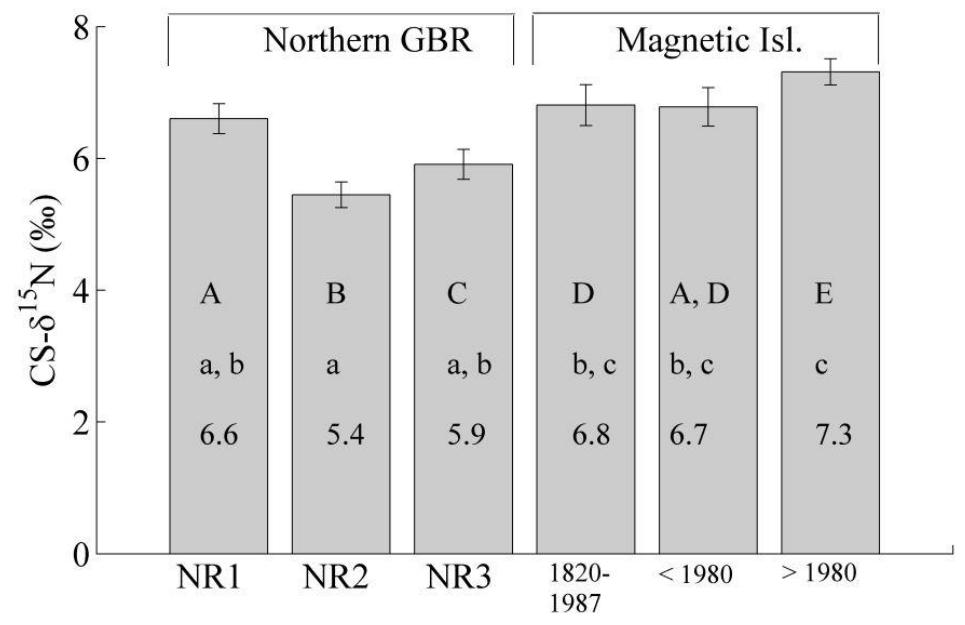

Figure 3 

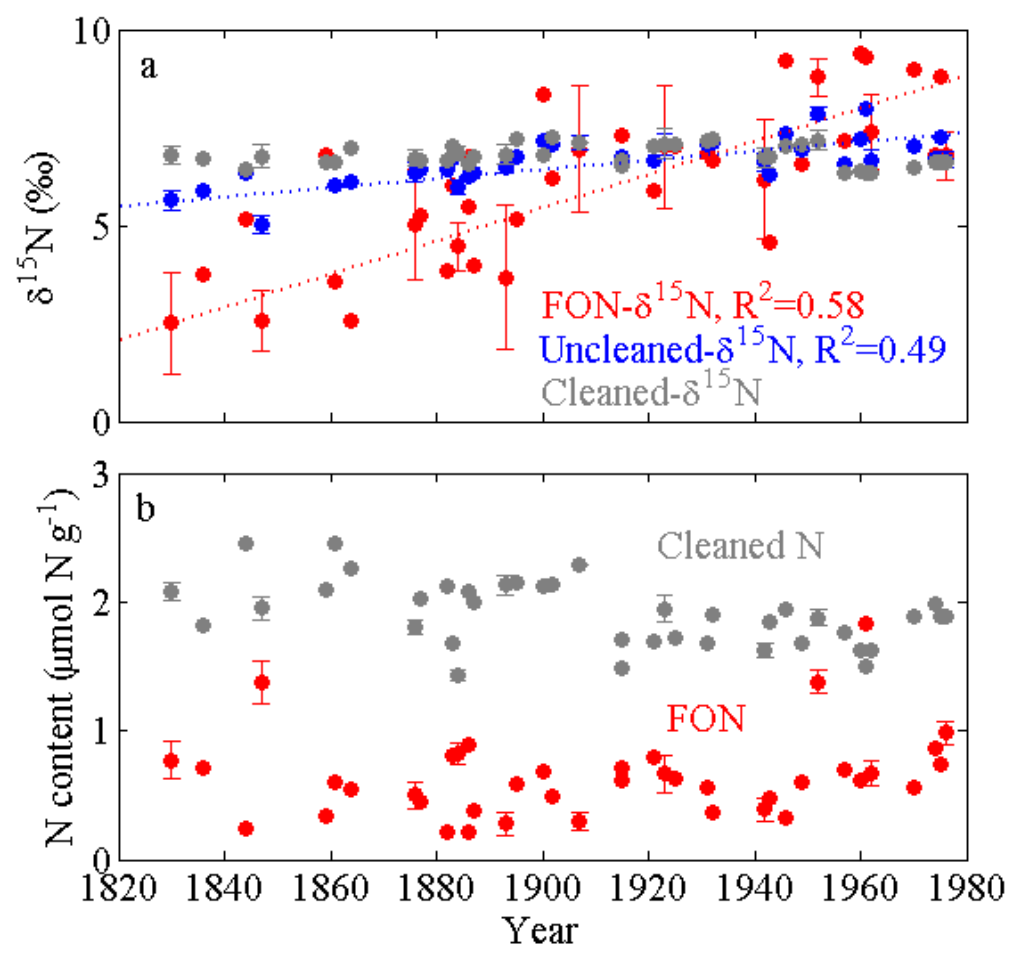

Figure 4 


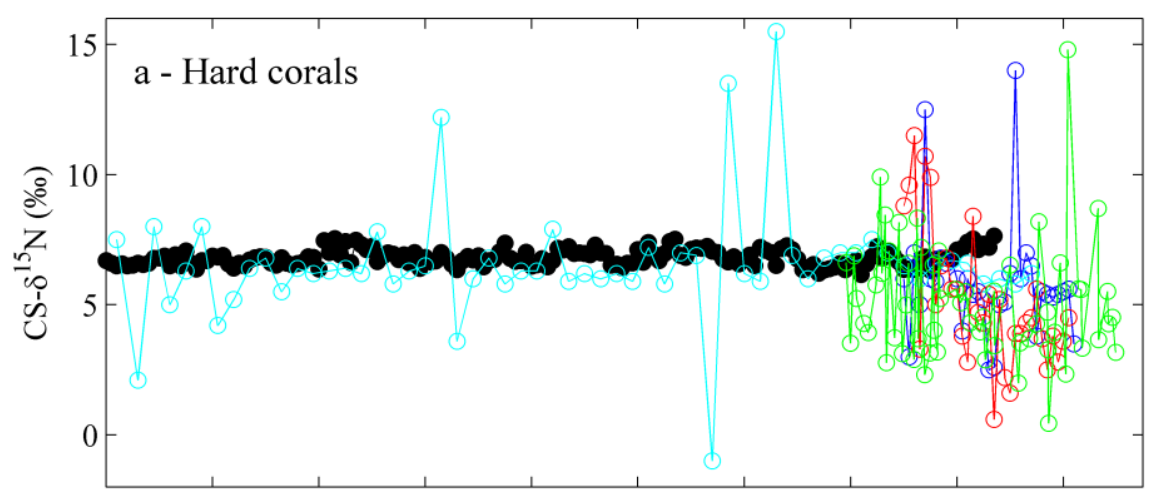

- This study

$\bigcirc$ GBR (Keswick Isl)

GBR (Whitsunday Isl)

- Bali (Amed)

- Ryukyu Isl

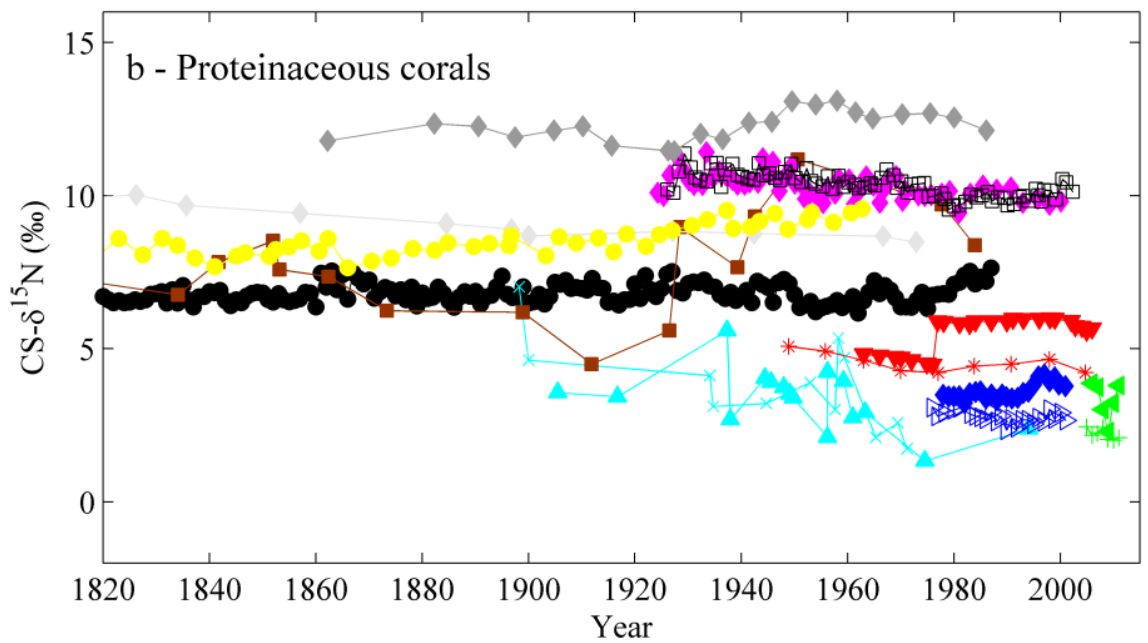

- This study Caribbean (Greater Antilles)

_ Caribbean (Lesser Antilles)

$\longrightarrow$ Jeddah (Harbour)

* Jeddah (Control)

$\longrightarrow$ Florida (Dirty)

$\gg$ Florida (Clean)

4 Mexico (Developed)

- Mexico (Undeveloped)

$\longrightarrow$ Gulf of Mexico

Hawaii (Makapuu)

$\longrightarrow$ Nova Scotia (a)

$\square$ Nova Scotia (b)

$\longrightarrow$ Tasmania

S.E USA

\section{Figure 5}

